\title{
AGREEMENTS CHANGING THE FORUM FOR RESOLVING MALPRACTICE CLAIMS
}

\author{
James A. Henderson, Jr.* \\ I \\ INTRODUCTION
}

The other articles in this symposium dealing with the role of private agreements in the medical malpractice context address issues that are primarily substantive: What standards of care should be applied in judging provider conduct? Should tort recoveries be subject to dollar limits? Might a workable no-fault system be devised for medical malpractice claims? In contrast to these substantive inquiries, this article focuses on procedure: Holding the traditional tort liability rules more or less constant, might questions of provider fault, causation, and damages be resolved in a forum other than a court of law? The first section of this article examines binding arbitration as a possible alternative to litigation. The second section explores the possibility of relying on pretrial screening panels.

II

\section{Binding Arbitration}

The major issues addressed in this section are whether and to what extent American courts will honor ex ante agreements ${ }^{1}$ between health care providers and recipients to have claims resolved by binding arbitration. The underlying premise of most proposals to submit medical malpractice claims to arbitration is that, viewed before the fact of an iatrogenic injury, arbitration is a preferable means of dispute resolution for everyone involved. Litigation imposes substantial costs on all parties to a medical malpractice claim; ${ }^{2}$ with its informal procedures ${ }^{3}$ and its bar against appeals, ${ }^{4}$ arbitration resolves

Copyright (C) 1986 by Law and Contemporary Problems

Frank B. Ingersoll Professor of Law, Cornell Law School. A.B., Princeton; LL.B., LL.M., Harvard Law School.

1. "Ex ante" refers to the fact that the agreements are entered into before the provision of the health care that causes injury. "Ex post," used hereafter in the text, refers to the period after the plaintiff learns of his injury.

2. See Sohn, An Examination of Alternatives to Suit in Doctor-Patient Disputes, 48 Alb. L. Rev. 669, 679 (1984) ("Arbitration costs are usually lower than the costs of formal litigation."); see also Redish, Legislative Response to the Medical Malpractice Insurance Crisis: Constitutional Implications, 55 TEx. L. REv. 759,768 (1977) (arbitration will reduce costs).

3. See Sohn, supra note 2, at 679 (“Arbitral procedures are relatively simple."). 
claims more quickly and less expensively. ${ }^{5}$ Recipients suffering relatively minor injuries that might not be worth a lawyer's time to litigate on a contingent fee basis may find arbitration to be a more viable, and thus preferable, alternative. ${ }^{6}$ Badly injured health care recipients tend to prefer jury trials when given a choice ex post. However, answers to the complex question of the relative advantages of litigation and arbitration are not clear. It is reasonable to assume that some recipients, choosing ex ante, would prefer arbitration over jury trial.

Providers have several reasons, in addition to the savings in transaction costs, for preferring arbitration. First, arbitration is a private affair, thus reducing the reputational losses associated with being a defendant (even an ultimately successful defendant) in a public malpractice trial. ${ }^{7}$ Second, the arbitrator (or arbitration panel) can be so selected as to possess greater technical expertise than law-trained judges and lay jurors, thus reducing the likelihood that errors in assessment of provider fault will occur. ${ }^{8}$ This last point may, of course, shade over into a somewhat different, perhaps less appropriate, reason for providers' preference for arbitration: The decisionmaker(s) may be chosen so as to be biased in the providers' favor. This issue is considered below in assessing the validity of certain types of arbitration agreements.

What, then, of the likelihood that courts will uphold ex ante agreements to submit medical malpractice claims to binding arbitration? From a more general perspective, we have come a long way from the time when courts, perhaps wary of attempts to curtail their jurisdiction, were reluctant to enforce contracts to submit legal disputes to binding arbitration. ${ }^{9}$ Today, in over two-thirds of the states, general statutes authorize agreements to

4. See N.Y. Civ. Prac. Law $\$ 7511$ (McKinney 1980); Sohn, supra note 2, at 680 ("Arbitral decisions enjoy a benefit of finality which judicial determinations do not because the grounds for appealing or modifying an arbitrator's award are extremely limited.").

5. See Sohn, supra note 2, at 679-80 ("Decisions are reached more rapidly in arbitration than in litigation[;] "overburdened courts force worthy plaintiffs to face long delays before they can obtain a remedy."); see also Henderson, Contractual Problems in the Enforcement of Agreements to Arbitrate Medical Malpractice, 58 VA. L. REv. 947, 960 (1972) ("A common objective of the contractual approaches is to avoid the costs and delays of litigation.").

6. See Madden v. Kaiser Found. Hosp., 17 Cal. 3d 699, 711-12, 552 P.2d 1178, 1186, 131 Cal. Rptr. 882, 890 (1976).

7. See Redish, supra note 2 , at 768 (arbitration reduces publicity).

8. See Sohn, supra note 2, at 679 ("Arbitration hearings are conducted before experts in the field of knowledge involved in the dispute. A formal trial . . . is conducted before a judge who may be unfamiliar with the technical subject matter which he must consider to decide the case."). The question of whether the makeup of the arbitration panel required in a Michigan statute violates a claimant's right to due process has produced a split of opinion. Compare Brown v. Siang, 107 Mich. App. 91, 309 N.W.2d 575 (1982) (plaintiff must prove that statute violates due process), with Jackson v. Detroit Memorial Hosp., 110 Mich. App. 202, 312 N.W.2d 212 (1981) (makeup of panel in itself is unconstitutional). Mich. Comp. LAws ANN. $\$ 600.5044$ (2) (West 1984) provides for a panel of three arbitrators with one physician.

9. See Henderson, supra note 5, at 970 ("An undertaking to arbitrate will not lightly be imputed by the courts. In fact, . . . it is still common practice to apply to arbitration clauses a more rigorous test of agreement than that applied to other contractual provisions."); see also Madden v. Kaiser Found. Hosp., 17 Cal. 3d 699, 706, 552 P.2d 1178, 1182, 131 Cal. Rptr. 882, 886 (1976) ("The early common law courts did not favor arbitration, and greatly limited the powers of arbitrators."). 
arbitrate; ${ }^{10}$ and in a smaller number of states, statutes specifically authorize (and to some extent regulate) arbitration agreements relating to medical malpractice claims." The issue of the constitutionality of these special statutes is beyond the scope of this paper. ${ }^{12}$ It suffices to say that most of these statutes have passed constitutional muster when challenged ${ }^{13}$ and that the availability of such a statute helps to substantiate the validity of an arbitration agreement that conforms to its terms. ${ }^{14}$

In most jurisdictions, the validity of agreements to arbitrate depends on general contract law principles. Most often, in the recurring context of a badly injured health care recipient trying to escape the arbitration agreement and obtain a jury trial, the question is whether at the time the agreement was entered into, the recipient, or someone authorized to act for the recipient, was adequately informed of the relevant implications and was in a position to exercise reasonably free choice in the matter. The sort of agreement that is most impervious to attack is one entered into between a prepaid health benefits provider and the representative(s) of a group of recipient-enrollees where it can be shown that the terms of the contract (including the arbitration agreement) are relatively fair on their face and were negotiated at arm's length. ${ }^{15}$ At the other extreme, the most vulnerable sort of agreement would be one entered into by an individual recipient seeking emergency medical treatment who signed the contract, unfair on its face, in haste after being told he could either sign it or go sleep in the snow. ${ }^{16}$

Obviously, there is a great deal of room for variation, both in fact patterns and in judicial responses thereto, between these two extremes. The fact patterns involved in recent appellate decisions may be grouped into four categories. In the first, claimants argue that their consent to submit to arbitration was not freely or knowingly given. "I was not told about the arbitration clause, nor did I understand the implications" is a typical argument. Some courts refuse to listen to such pleas when the medical

10. For a list of citations to these so-called "modern arbitration statutes" see Ladimer \& Solomon, Medical Malpractice Arbitration: Laws, Programs, Cases, 653 Ins. L.J. 335, 362 (1977).

11. Id. at 358-61.

12. See generally Hurst, Alternatives to Litigation: Pretrial Screening and Arbitration of Medical Malpractice Claims: Has Missouri Taken a Giant Step Backward?, 50 UMKC L. Rev. 188-209 (1982); Mengel, The Constitutional and Contractual Challenges to Michigan's Medical Malpractice Arbitration Act, 59 U. DET. J. URB. L. 319 (1982); Redish, supra note 2.

13. See generally Mengel, supra note 12.

14. See Ramirez v. Superior Court, 103 Cal. App. 3d 746, 749, 163 Cal. Rptr. 223, 224 (1980) ("'A] patient who has signed an admission agreement which complies with [CAL CIv. Proc. Code $\S 1295$ (West 1982)] . . . and which requires arbitration of all medical malpractice claims may resist arbitration on the ground that the agreement was not entered into knowingly and voluntarily."); Madden v. Kaiser Found. Hosp., 17 Cal. 3d 699, 713, 552 P.2d 1178, 1187, 131 Cal. Rptr. 882, 891 (1976) ("Legislature enacted the specific language of the California Arbritation Act [CaL. CIv. Proc. CODE $\S \S 1280-1295$ (West 1982)] to govern the enforcement of arbitration agreements"). See generally Redish, supra note 2.

15. See, e.g., Henderson, supra note 5 , at 958.

16. See Henderson, supra note 5, at 993-97. The Ohio statute, Ohio Rev. Code Ann. $\S 2711.23(\mathrm{~A})$ (Baldwin 1984), provides that the agreement must state that the continued provision of medical care is not predicated on the patient's agreement to submit his claims to arbitration. 
treatment received was not emergency in nature and when the agreement was both signed ahead of time and fair on its face. ${ }^{17} \mathrm{~A}$ larger number of courts will conduct a preliminary hearing to allow the judge to determine the factual issues relevant to the validity of the agreement to arbitrate. ${ }^{18}$ Reading the recent cases, one gets the impression that a claimant must show some element of egregious conduct on the provider's part, such as fraud or misrepresentation, in order for the court to set aside the agreement to arbitrate. $^{19}$ It must be emphasized, however, that the provider is not insulated from the risks attendant to the factfinding process itself; and some courts appear to be looking for an excuse to allow the claimant to avoid arbitration and get into court with his malpractice claim. ${ }^{20}$

The second category of arbitration agreement cases involves claimants who argue that even if the agreement is to some extent valid and binding, they did not sign the agreement and therefore are not bound by.it. On the whole, courts have been willing to hold nonsignatory claimants bound by a consent to arbitrate given by someone in a position to represent the claimants' interests. Thus, Army depot employees were held bound by the consent given on their behalf by the Civil Service Commission notwithstanding their argument that none of their elected representatives participated in the negotiations. $^{21}$ In similar fashion, a minor child is bound by his parents' consent in a group benefits contract, ${ }^{22}$ even for injuries allegedly caused by prenatal care provided to his mother. ${ }^{23}$ In addition, a wife bringing an action for her husband's death, arguing that her rights are not derivative under the wrongful death statute and that therefore she is free as a nonsignatory to sue in tort, will be held bound by her husband's consent to arbitrate. ${ }^{24}$ A typical case of this latter type would involve a group health benefits program to which the signatory spouse subscribes on a "family plan" basis; when the agreement to arbitrate is contained in a contract between one spouse and the provider of specified care on a one-shot basis, the nonsignatory spouse bringing a nonderivative tort action may not be bound by the agreement. ${ }^{25}$

17. See, e.g., Horn v. Cooke, 118 Mich. App. 325, 740 N.W.2d 558 (1982) (court will hold hearing concerning illiterate recipient's allegation that she was fraudulently induced to agree, but not concerning allegations that she had not read the agreement or did not understand it).

18. See, e.g., Ramirez v Superior Court, 103 Cal. App. 3d 746, 163 Cal Rptr. 223 (1980); McCloy v. Dorfman, 123 Mich. App. 710, 333 N.W.2d 338 (1983); Miner v. Walden, 101 Misc. 2d 814,442 N.Y.S.2d 335 (1979).

19. See, e.g., Ramirez v. Superior Court, 103 Cal. App. 3d 746, 754-55, 163 Cal. Rptr. 223, 228 (1980); McCloy v. Dorfman, 123 Mich. App. 710, 710, 333 N.W.2d 338, 340 (1983).

20. See, e.g., Miner v. Walden, 101 Misc. 2d 814, 422 N.Y.S.2d 335 (1979) (form stated recipient's signature was "required;" provider was a doctor with many years of college, medical, and dental school training, while plaintiff had only an eleventh grade education).

21. See Dinong v. Superior Court, 102 Cal. App. 3d 845, 162 Cal. Rptr. 606 (1980).

22. See Doyle v. Giuliucci, 62 Cal. 2d 606, 401 P.2d 1, 43 Cal. Rptr. 697 (1965).

23. See Wilson v. Kaiser Found. Hosp., 141 Cal. App. 3d 891, 190 Cal. Rptr. 649 (1983).

24. See, e.g., Hawkins v. Superior Court, 89 Cal. App. 3d 413, 152 Cal. Rptr. 491 (1979). But see Rhodes v. California Hosp. Medical Center, 76 Cal. App. 3d 606, 143 Cal. Rptr. 59 (1978).

25. See, e.g., Rhodes v. California Hosp. Medical Center, 76 Cal. App. 3d 606, 143 Cal. Rptr. 59 (1978). 
A third category of cases involves attempts by claimants to construe the agreements, conceded to be valid and binding on them, in such a way as to avoid their application to the tort cases being brought. Thus, in a recent California case, the plaintiff sought to resist the provider-defendant's motion to compel arbitration on the ground that the amended complaint contained an intentional tort count, a basis for recovery that was not included in the arbitration agreement. The court of appeals granted the defendant's motion, pointing out that while an introductory section of the relevant California statute seemed to limit it to negligence cases, the contractual language mandated by the statute was broader and included intentional torts in the category of disputes which could be decided by arbitration. ${ }^{26}$

Another subset of this third category of "contract construction" cases involves tort actions brought by signatory plaintiffs against nonsignatory defendants. Clearly, an agreement to arbitrate entered into by a health care recipient and a provider does not bar tort actions by the recipient against providers who are not parties to the agreement. But may the recipient avoid the agreement even with respect to the signatory provider by joining the signatory provider as a tort defendant with nonsignatory providers and arguing that the signatory provider is an indispensable party? A leading California decision suggests that he may not; the recipient cannot avoid an otherwise valid agreement to arbitrate by joining signatory and nonsignatory defendants in a single tort action. ${ }^{27}$

The final category of cases involves agreements whose terms can be attacked as unfair. Thus, an intermediate appellate court in New York set aside a contract to arbitrate on the ground, among others, that the health care provider retained the option-the only such option available to either partyto take the recipient to court to collect unpaid fees. ${ }^{28}$ An intermediate appellate court in California responded in similar fashion to an agreement that gave the provider, but not the recipient, the right to reject an unfavorable arbitration decision and resubmit the matter to arbitration. ${ }^{29}$ Additionally, an intermediate court in Michigan held unconstitutional a statutory provision that one member of the required three-member arbitration panel must be a physician or, if the claim is against a hospital only, a hospital administrator. ${ }^{30}$ The court concluded that the requirement denied the recipient's due process right to a fair and impartial tribunal. ${ }^{31}$

In addition to the requirement that the agreement to arbitrate be fair to recipients, courts have also reviewed arbitration decisions to make sure that the procedures actually followed conformed to the procedures expressly or

26. See Herrera v. Superior Court, 158 Cal. App. 3d 255, 204 Cal. Rptr. 553 (1984).

27. See Madden v. Kaiser Found. Hosp., 17 Cal. 3d 699, 714, 552 P.2d 1178, 1188, 131 Cal. Rptr. 882, 892 (1976).

28. See Miner v. Walden, 101 Misc. 2d 814, 442 N.Y.S.2d 335 (1979).

29. See Beynon v. Garden Grove Medical Group, 100 Cal. App. 3d 698, 161 Cal. Rptr. 146 (1980).

30. See McCloy v. Dorfman, 123 Mich. App. 710, 333 N.W.2d 338 (1983).

31. Id. at 713,333 N.W.2d at 339 . 
impliedly called for in the agreements. Thus, a California court granted a recipient's petition to vacate an arbitration panel's decision for the defendant providers when the proof indicated that the medical member of the arbitration panel had not disclosed an ongoing business relationship with the law firm representing the defendants. ${ }^{32}$

In reflecting on these judicial reactions to agreements to submit medical malpractice claims to binding arbitration, two general propositions emerge. First, providers relying on such agreements must expect a measure of judicial scrutiny on a case-by-case basis; it is all but impossible to nail down the validity issue once and for all ahead of time. Second, for the agreement to pass muster, it must appear to be fair to the recipient. Taken together, these propositions present a somewhat troubling picture for future reliance on arbitration by health care providers.

The source of concern may be easily identified. To the extent that arbitration agreements must make significant concessions to prospective patient-plaintiffs in order to be acceptable to courts, they may lose their appeal to providers. Arbitration works in commercial settings because it relies on the willingness of both sides to trust the arbitrator to try to reach decisions that fit into the fabric of the give-and-take of the marketplace out of which the dispute arises. Both sides are likely to be in an ongoing relationship, and will have opportunities in the future to adjust their positions in light of the outcome. Additionally, both sides value the privacy afforded by arbitration.

In the typical medical malpractice context, only the provider is in a position analogous to the firm in traditional commercial arbitration. The provider's ongoing activities are jeopardized by the tort claim; he or she would prefer to resolve the dispute as quickly and privately as possible. In contrast, the recipient-claimant is a one-shot player, substantially outside the system of health care provision. Viewed ex post, the recipient has no interest in protecting the fabric of customary dealings regarding the provision and receipt of health care; indeed, the greater the disruption caused by the claim, and the greater the publicity generated by it, the greater are the recipient's chances to exact a favorable settlement in a tort action. Thus, there is an unavoidable tension inherent in submitting medical malpractice claims to binding arbitration. At the level of "deeper rhythms," there is a nagging "arrhythmia," if you will. The parties may arrive at an agreement ex ante; but the "fit" between process and controversy is not exactly right-and thus pressures persist for courts to set aside agreements that appear asymmetrically beneficial to health care providers.

What will the future-the next ten years or so--hold for attempts to move medical malpractice out of court and into binding arbitration (again assuming substantive liability rules remain essentially the same)? Recent case law is inconclusive. A trend favoring upholding these agreements may be

32. See Wheeler v. St. Joseph Hosp., 63 Cal. App. 3d 345, 133 Cal. Rptr. 775 (1976). 
discernible over the last twenty or thirty years. Where that trend will lead over the next ten years, however, is not so clear. Scanning a farther horizon, ex ante agreements to arbitrate will provide a limited, but useful, response to the difficulties presented by adjudicating medical malpractice claims in court. Nevertheless, the deep-seated tension and attendant uncertainties identified above will probably limit its usefulness in the long run.

Might the limits on the availability and effectiveness of agreements to arbitrate be avoided by imposing binding arbitration by statute? That appears doubtful. At the state level, such an approach would confront substantial difficulties on constitutional grounds.'Adjusting substantive rights is one thing: Courts that have concluded that a substantive legal change denies claimants constitutionally guaranteed access to courts and to jury trial are clearly bootstrapping; these procedural rights presuppose underlying substantive rights but do not embody them. ${ }^{33}$ In contrast, however, to hold existing substantive rights in place and to force binding arbitration on tort claimants would legitimately be found to run afoul of the "right-to-access" and "jury trial" provisions in state constitutions. ${ }^{34}$ And while a federal statute imposing binding arbitration would presumably avoid the constitutional difficulties, ${ }^{35}$ such federal legislation appears unlikely. ${ }^{36}$

\section{III}

\section{Pretrial Screening Panels}

Slightly more than half of the states have statutes that require medical malpractice claimants to take their cases before screening panels that include, but are not limited to, medical people with appropriate professional expertise. Although these panels are not adopted via contract, but rather are imposed by statute, experience under them is relevant to the present inquiry inasmuch as it sheds light on the possible gains to be realized by parties in other states adopting such panels, or variations on that theme, by contract. The screening panels determine whether the claim is meritorious. ${ }^{37}$ The procedures are informal; the decisions are not binding. Thus, regardless of whether or not the screening panel approves the claim, the claimant may proceed to full trial in court. The hope, of course, is that claimants who receive a negative assessment will not go on to trial, especially when that assessment is admissible later in court or when the risks of litigating are increased by

33. Some state courts have disguised substantive due process objections to "no-fault" legislation by holding that such statutes violate the right-to-access provisions of their state constitutions. See, e.g., Sunspan Eng'g \& Constr. Co. v. Spring-Lock Scaffolding Co., 310 So. 2d 4 (Fla. 1975).

34. E.g., Idaho Const. art. I, § 18; Kansas Const. Bill of Rights $§ 18$.

35. Cf. Usery v. Turner Elkhorn Mining Co., 428 U.S. 1 (1976).

36. The medical malpractice "crisis" lacks a substantial interstate aspect-a provider typically confronts the law of a single jurisdiction. In contrast, the so-called "products liability crisis" has a significant interstate dimension, and yet even in this area federal reform legislation appears unlikely in the near future.

37. See generally Sohn, supra note 2, at 682 . 
provisions charging additional litigation costs to a party losing in both forums.

Although a few courts have had trouble with the constitutionality of these screening statutes on the ground that admitting negative assessments interferes with established judicial process, ${ }^{38}$ this argument appears spurious and has been rejected by a majority of courts that have considered it. ${ }^{39}$ Properly drafted statutes should pass constitutional muster.

The problem with these screening panels, then, is not so much with their validity as with their utility. Some observers have concluded that screening panels add a further layer of transaction costs that are not recaptured by net gains in the form of weeding out weaker claims. ${ }^{40}$ Once again, the problem is probably traceable to the deep-level tension referred to earlier between designing a screening panel that is potentially biased in favor of providersfor instance, a three-member panel, all of whom are health care providersand getting courts to approve such a panel as fundamentally fair to injured recipients.

Might providers and recipients in states other than those with screening panel statutes agree, ex ante, to submit malpractice claims to such a procedure? It seems likely that such agreements would have an easier time of it in court, given the less onerous implications for recipient-claimants. However, contracts might face greater difficulties than do statutes in imposing their terms on later tort actions. Private parties may not be able, via ex ante contractual agreements, to determine what evidence is, and is not, admissible at trial.

\section{IV}

\section{CONCLUSION}

Binding arbitration and screening panels offer limited benefits to health care providers seeking to ease the difficulties they are encountering in medical malpractice actions under existing law. Something of a dilemma is presented. In order to pass muster with reviewing courts, these alternative arrangements must make considerable concessions to the interests of health care recipients. Once these concessions are made, one wonders how much help the alternatives offer.

There might be more reason for optimism about alternative dispute resolution mechanisms if the ongoing assumption that the substantive liability rules are to be retained unchanged were relaxed. If a system such as the one proposed in the Designated Compensable Event (DCE) Project ${ }^{41}$ were to be implemented, so that provider fault would no longer be the basis for plaintiffs'

38. See, e.g., Wright v. Central Du Page Hosp. Ass'n, 63 Ill. 2d 313, 347 N.E.2d 736 (1976); Simon v. St. Elizabeth Medical Center, 3 Ohio App. 3d 164, 355 N.E.2d 903 (1976).

39. See Lacy v. Green, 428 A.2d 1171, 1175 (Del. Super. Ct. 1981) (tabulation of cases).

40. See, e.g., Sohn, supra note 2, at 686-87.

41. Tancredi, Designing a No-Fault Alternative, Law and Contemp. Probs., Spring 1986, at 277, 280-83. 
recoveries in connection with most serious malpractice claims, binding arbitration might play a more significant role. Indeed, were the DCE approach implemented in connection with, for example, a prepaid health benefits program, an agreement to submit disputes to binding arbitration would have found a setting much more closely analogous to the traditional settings of binding commercial or labor arbitration. The fit between substance and process would, in that event, be better, and one could expect the courts to react more favorably. 
